\title{
THE RECORD OF PLIOCENE SEA-LEVEL CHANGE AT ENEWETAK ATOLL
}

\author{
Bruce R. Wardlaw* and Terrence M. Quinn $\dagger$ \\ ${ }^{*}$ U.S. Geological Survey, National Center, MS 970, Reston, VA 22092, U.S.A. \\ †Department of Geological Sciences, The University of Michigan, Ann Arbor, MI 48109-1063, U.S.A.
}

\begin{abstract}
Detailed seismic stratigraphy, lithostratigraphy, and chemostratigraphy indicate that atoll-wide subaerial exposure surfaces (major disconformities) developed during major sea-level lowstands form prominent seismic reflectors and are coincident with biostratigraphic breaks in the Plio-Pleistocene on Enewetak Atoll. Sea-level models based on the stratigraphic position and age of major disconformities suggest a maximum sea-level highstand elevation of $36 \mathrm{~m}$ above present sea level and a maximum sealevel lowstand elevation of $63 \mathrm{~m}$ below present sea level for the Pliocene.
\end{abstract}

\section{INTRODUCTION}

The PEACE (Pacific Enewetak Atoll Crater Exploration) Program, sponsored by the Defense Nuclear Agency (DNA), consisted of a multidisciplinary study of geologic, geophysical and material properties data from areas in and near KOA and OAK craters (Fig. 1), and a reexamination of the information obtained from the previous programs on Enewetak (see Tremba et al., 1990; Henry and Wardlaw, 1991). Detailed seismic reflection studies (Grow et al., 1986) combined with detailed lithologic (Henry et al., 1986) and geochemical (Quinn, 1991) studies of Miocene to Recent carbonates from numerous PEACE Program boreholes provide a unique data set in which to examine the history of Pliocene sea-level change at Enewetak. PEACE Program reference boreholes KAR-1, OAR-2A/2, OOR17 (Fig. 1) recovered Lower Miocene to Recent carbonates. Borehole XEN-3, which was drilled on Enjebi Island as part of the EXPOE Project (Exploratory Program on Eniwetok; see Couch et al., 1975), recovered Upper Pliocene to Recent carbonates and provides a reference borehole outside of the lagoon. Boreholes through the center of KOA and OAK craters (KBZ-4, OBZ-4) were utilized for aspects of biostratigraphy below the shallow crater zones (Bybell and Poore, in press; Gibson and Margerum, in press) but are significantly disturbed above the Lower Miocene and are not used here (see Tremba et al., 1990).

A previous reconstruction of a Neogene sea-level history from Enewetak Atoll was largely based on the Sr-isotope stratigraphy (SIS) of a single borehole (KAR-1, Halley and Ludwig, 1987, 1989a; Ludwig et al., 1988). The Sr-isotope chronostratigraphy of that borehole was interpreted to indicate that a dozen major high stands of sea level were recorded in the last $20 \mathrm{Ma}$ at Enewetak, each representing a sea-level rise of 7 $70 \mathrm{~m}$ (Halley and Ludwig, 1987, 1989a). The recent development of an SIS from borehole OOR-17 located less than $15 \mathrm{~km}$ from KAR-1, has documented intralagoon variability in the $\mathrm{Sr}$-isotope data at Enewetak resulting from the complex interaction of diagenetic, sedimentologic, and possible submarine erosional processes (Quinn et al., in press). Discrepancies between the biochronology and Sr-isotope chronology of Enewetak Atoll have been discussed previously (Wardlaw, 1989; Halley and Ludwig, 1989b), and we develop our record of Pliocene sea-level exclusively using biochronologic data.

Lagoon-wide seismic reflections coincide with previously-defined major disconformities (i.e. atollwide subaerial exposure surfaces) and local biozone boundaries within the carbonate sequence at Enewetak. Several minor (i.e. local) disconformities represent local subaerial exposure surfaces and paleophreatic lenses (Quinn, 1989, 1991), and are manifested as local seismic reflections, generally concentrated near the atoll margin. In this study, we concentrate on reconstructing a sea-level history based on the stratigraphic distribution of major disconformities because these disconformities coincide with resolvable age differences in the biochronology of Enewetak. Few of the minor disconformities coincide with local biozone boundaries. Moreover, the concentration of minor disconformities in the Pleistocene sequence relative to the Pliocene sequence at Enewetak suggests that sea-level change in the Pleistocene was more variable than in the Pliocene, or that pervasive diagenetic alteration of the Pliocene sequence has obscured the record of minor disconformities.

\section{MAJOR DISCONFORMITIES}

Previous workers have recognized 9 major disconformities to a maximum depth of $371 \mathrm{~m}$ in the PEACE reference boreholes (Wardlaw and Henry, 1986). Six of these major disconformities are within the PlioPleistocene and are listed in Table 1.

\section{Shallow Seismic Stratigraphy of Enewetak}

The two very shallow reflectors shown by singlechannel seismic survey (R10 and R20, Robb et al., 


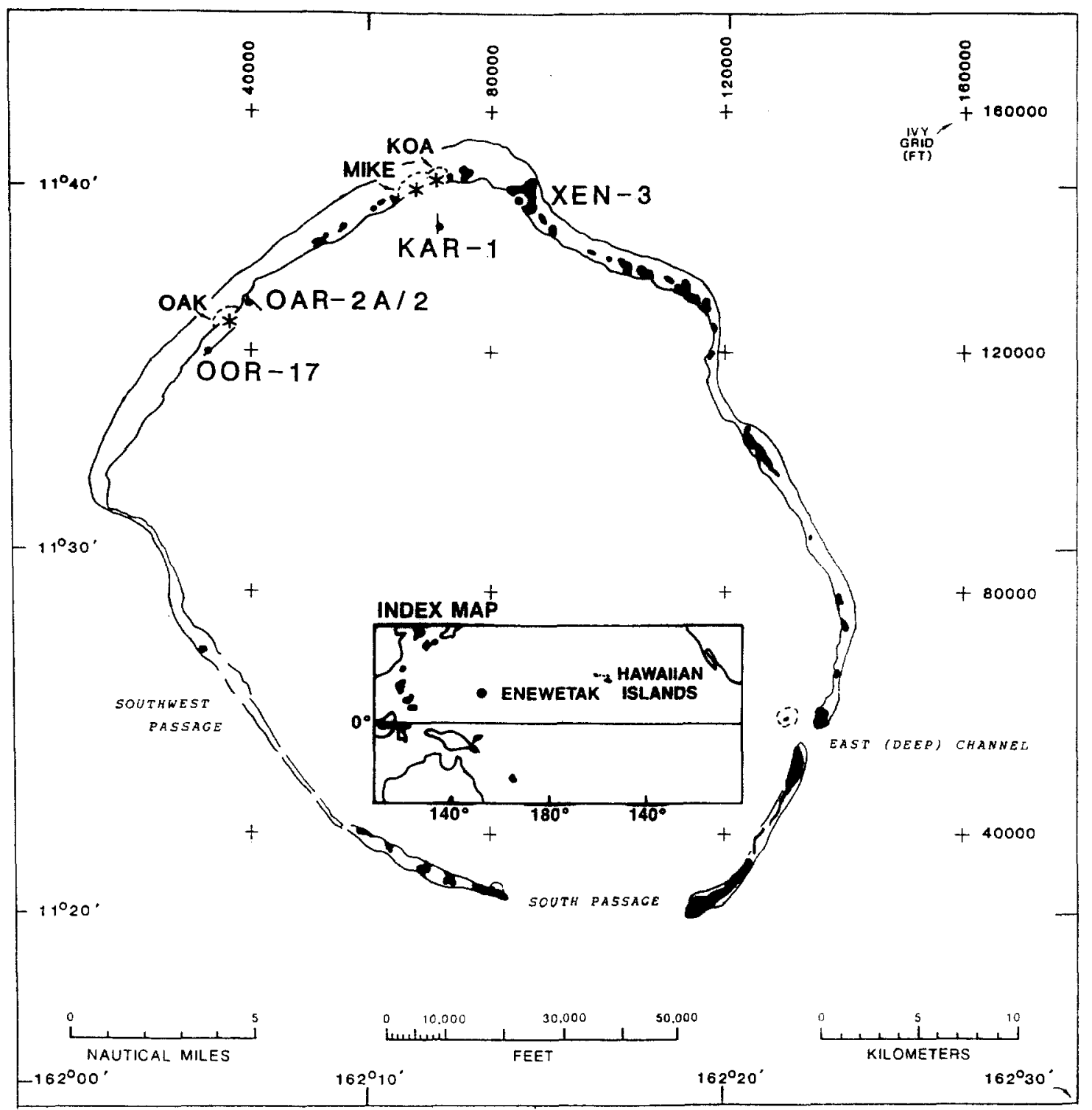

FIG. 1. Location of Enewetak Atoll (insert) and location of reference boreholes and seismic reflection lines shown in Figs 2-4.

TABLE 1. Depth of major disconformities in reference boreholes, in feet and meters, below seafloor (BSF) and below sea level (BSL)

\begin{tabular}{|c|c|c|c|c|c|c|c|c|c|c|c|c|c|}
\hline \multirow[b]{2}{*}{ Borehole } & & \multicolumn{2}{|c|}{1} & \multicolumn{2}{|c|}{2} & \multicolumn{2}{|c|}{3} & \multicolumn{2}{|c|}{4} & \multicolumn{2}{|c|}{5} & \multicolumn{2}{|c|}{6} \\
\hline & & BSF & BSL & BSF & BSL & BSF & BSL & BSF & BSL & BSF & BSL & BSF & BSL \\
\hline \multirow{2}{*}{ KAR-1 } & FT & 45.6 & 150.7 & 131.6 & 236.7 & 215.8 & 320.9 & 240.6 & 345.7 & 278.9 & 384.0 & 482.0 & 587.1 \\
\hline & $\mathbf{M}$ & 13.9 & 45.9 & 40.1 & 72.2 & 65.8 & 97.8 & 73.4 & 105.4 & 85.0 & 117.1 & 147.0 & 179.0 \\
\hline \multirow{2}{*}{ XEN-3 } & FT & 51.7 & - & 141.2 & - & 215.0 & - & 249.8 & - & 275.0 & - & - & - \\
\hline & $\mathbf{M}$ & 15.8 & - & 43.0 & - & 65.5 & - & 76.2 & - & 83.8 & - & - & - \\
\hline \multirow{2}{*}{ OAR $-2 A / 2$} & FT & 25.7 & 136.2 & 90.7 & 201.2 & 199.5 & 310.0 & 245.1 & 355.6 & 300.1 & 410.6 & 442.5 & 556.7 \\
\hline & $M$ & 7.8 & 41.5 & 27.7 & 61.3 & 60.8 & 94.5 & 74.7 & 108.4 & 91.5 & 125.2 & 134.9 & 169.7 \\
\hline \multirow{2}{*}{ OOR-17 } & FT & 70.7 & 125.9 & 136.4 & 191.6 & 218.6 & 273.8 & 307.9 & 363.1 & 350.5 & 405.7 & 497.2 & 552.4 \\
\hline & M & 21.6 & 38.4 & 41.6 & 58.4 & 66.6 & 83.5 & 93.9 & 110.7 & 106.9 & 123.7 & 151.6 & 168.4 \\
\hline
\end{tabular}


1986) correlate exactly with the upper two disconformities (Wardlaw and Henry, 1986) and the boundaries of the upper two local biostratigraphic zones (Cronin et $a l ., 1986)$. This demonstrates that disconformities, created by subaerial exposure, represent seismic reflectors. These breaks also represent a changeover in biota commonly expressed as a boundary in the biostratigraphic zonation.

Multichannel seismic-reflection survey (Grow et al., 1986) shows several reflectors in the area of the three PEACE reference boreholes of this study (Figs 12, 25, 26 and 28 of Grow et al., 1986; Figs 2-4 of this paper). These reflectors have been tied directly to the borehole descriptions (Henry et al., 1986), interpretations (Wardlaw and Henry, 1986; Tremba et al., 1990), and the biostratigraphy (see 'Biostratigraphy of Enewetak Reference Boreholes' Section). The major reflectors recognized can be traced across most of Enewetak Lagoon (unpublished lines 401, 405, 406; the position of these lines is shown in Grow et al., 1986) and represent major disconformities. The seismic stratigraphy for the Late Miocene through Holocene sediments of Enewetak can be summarized into five zones (Fig. 5): (1) upper seismic doublet; (2) 'transparent'; (3) strong seismic reflectors; (4) inconsistent, variably arranged reflectors; and (5) inconsistent, flat reflectors.

The upper seismic doublet are the closely spaced reflectors R10 and R20 (Robb et al., 1986; Grow et al., 1986) and mark the top of the Pleistocene. The top reflector is major disconformity 1 of Wardlaw and Henry (1986). The transparent zone is a zone of few reflectors across the lagoon. One weak reflector is persistent throughout most of the lagoon and represents major disconformity 2 of Wardlaw and Henry (1986). This sequence represents Plio-Pleistocene sediments. The zone of strong reflectors represents at least three persistent reflectors (major disconformities 3, 4 and 5 of Wardlaw and Henry, 1986) and represents Early and Late Pliocene sediments. The zone of inconsistent, variably arranged reflectors represents the pervasively-calcitized limestone of sedimentary package 3 of Wardlaw and Henry (1986). One somewhat persistent reflector is present near the base of this zone (major disconformity 6). The zone of inconsistent, flat reflectors represents the transition from altered (sedimentary package 3 ) to unaltered (sedimentary package 4 of Wardlaw and Henry, 1986) sediments of Late Miocene to Early Pliocene age. Several local, strong, horizontal reflectors are represented, but none are persistent in this zone.

Local reflectors, generally beneath the atoll margin, represent local discontinuities on the atoll margin, generally due to subaerial exposure of a local extent, but not involving the whole atoll, in contrast to major disconformities. Figure 2 (KAR-1) represents the seismic profile typical of the lagoon and is the most lagoonward of the three profiles (Fig. 1). Figures 3 and 4 (OAR-2A/2 and OOR-17) represent profiles close to the atoll margin showing increasingly more local reflectors toward and along the margin.

\section{Biostratigraphy of Enewetak Reference Boreholes}

Recently, the planktic nannofossil and foraminifer control for dating the reference borehole samples has been summarized by Bybell and Poore (in press; Fig. $5)$. Though the planktic material is generally sparse, it ties well to the local biostratigraphic zones defined on the distribution of benthic ostracodes and foraminifers (Cronin et al., 1986). We have noted previously that this zonation, in turn, ties well to the major disconformities recognized by Wardlaw and Henry (1986). This allows relatively detailed dating of the sediments.

Because we rely entirely on the biostratigraphic dating of the boreholes, it is important to note some of the basic assumptions used by Bybell and Poore (in press) and how these compare to the generally accepted standard (Berggren et al., 1985). Bybell and Poore (in press) considered the NN 11/NN 12 boundary as the Miocene/Pliocene boundary based on the LAD (Last Appearance Datum) of Discoaster quinqueramus which Berggren et al. (1985) placed at 5.6 Ma, some 0.4 Ma older than the actual boundary as recognized by Berggren et al. (1985). Lower Zone NN 19 (19a, Pliocene) is recognized by the FAD (First Appearance

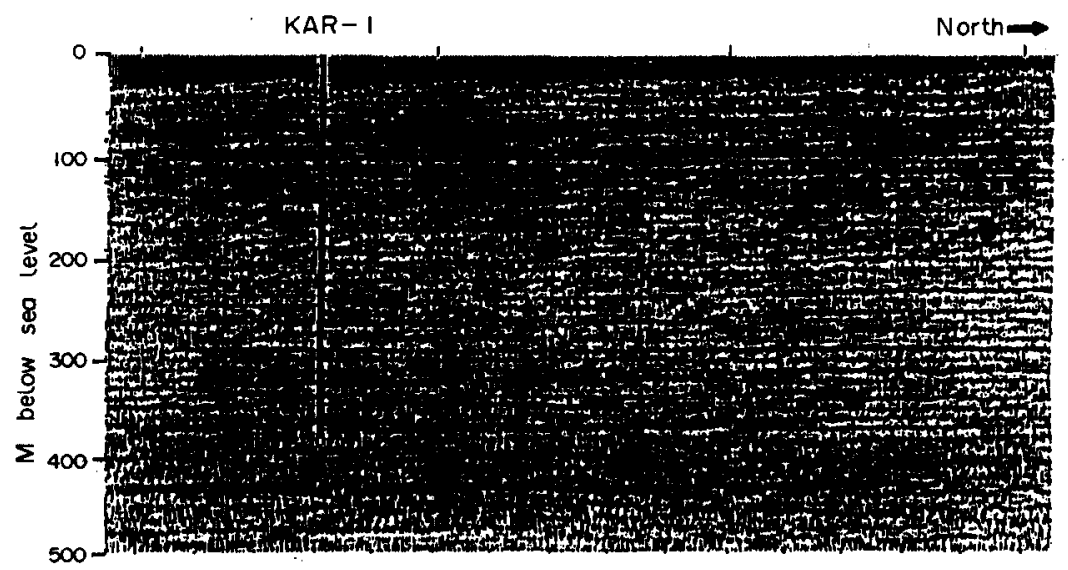

FIG. 2. Migrated depth section of part of seismic reflection profile $306 \mathrm{~V} 1$ at drill site KAR-1 (from Grow et al., 1986). Numbers $1-6$ represent major disconformities $1-6$. 


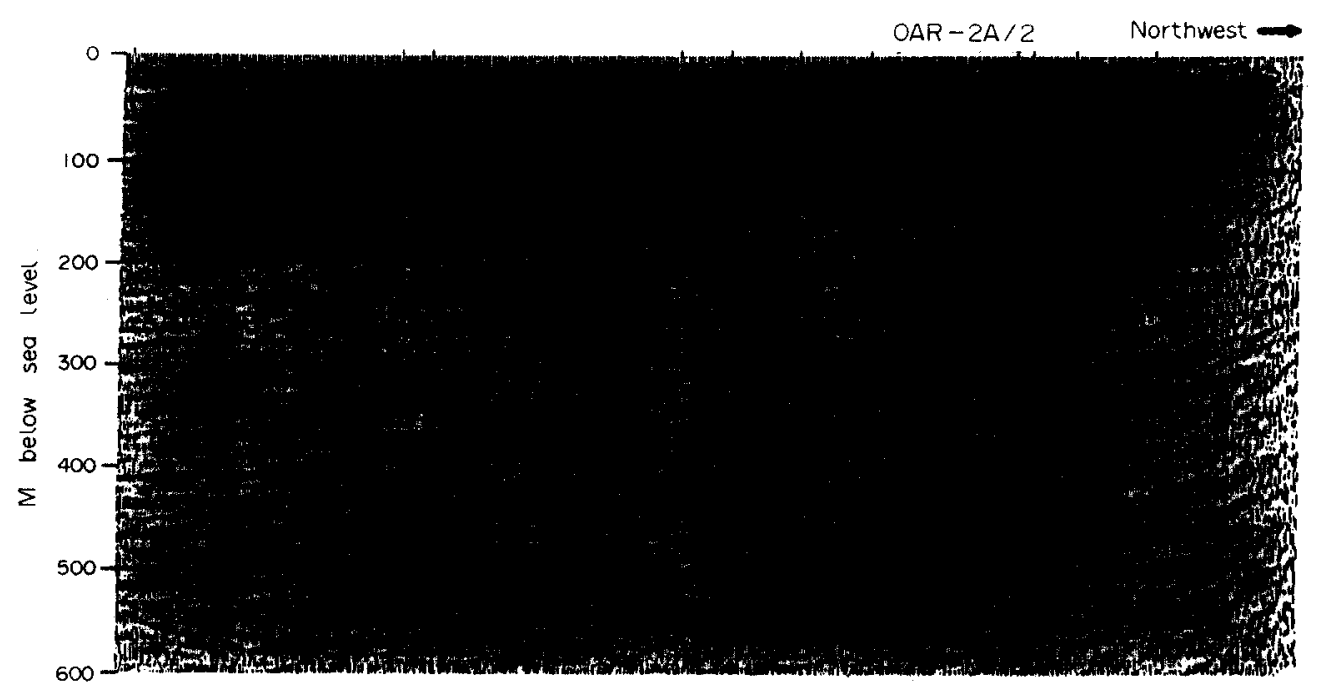

FIG. 3. Migrated depth section of part of seismic reflection profile $121 \mathrm{VI}$ near drill sites OAR-2A/2 (from Grow et al., 1986). Numbers 1-6 represent major disconformities 1-6.

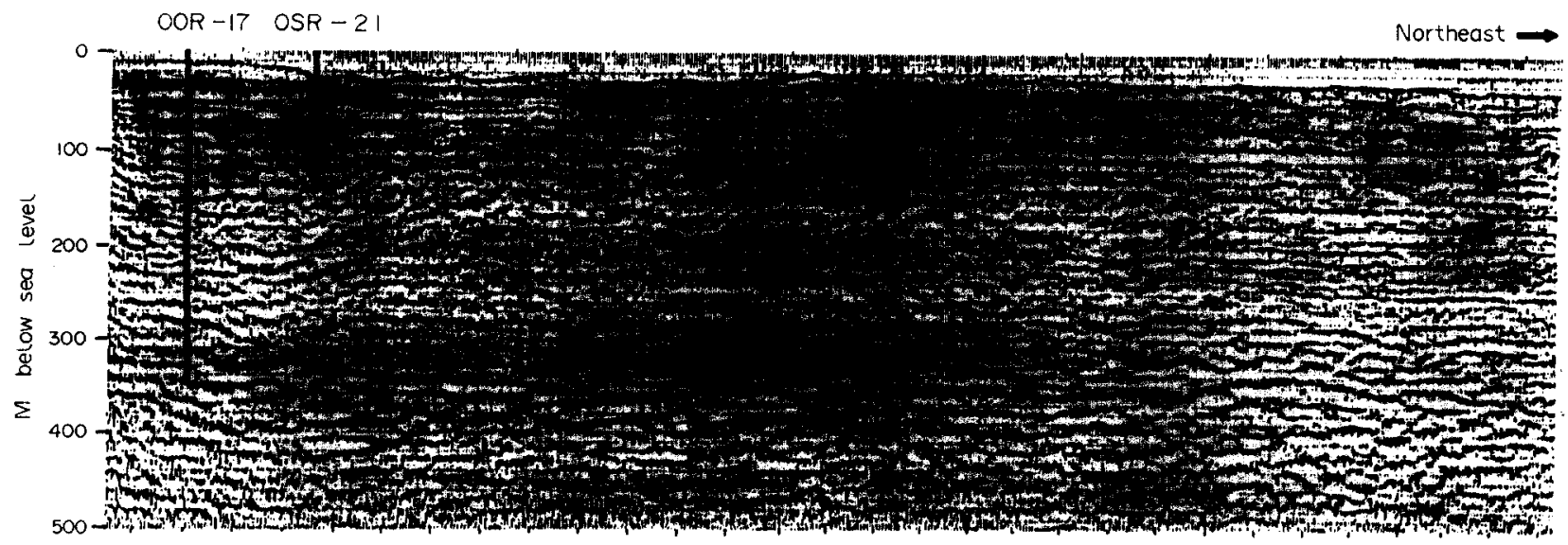

FIG. 4. Migrated depth section of part of seismic reflection profile $109 \mathrm{Vl}$ at drill site OOR-17 (from Grow et al., 1986). Numbers $1-6$ represent major disconformities $1-6$.

Datum) of Gephyrocapsa large species (1.74 Ma), and the LAD of Calcidiscus macintyrei (1.45 Ma) by Bybell and Poore (in press). Berggren et al. (1985) recognize the Pliocene part of Zone NN 19 (19a) as 1.9-1.6 Ma. Most shallow occurrences of Gephyrocapsa large species appear to be $G$. oceanica (FAD of $1.68 \mathrm{Ma}$ ). Two occurrences of Gephyrocapsa are anomalously low in the section (XEN-3, 248 feet; KBZ-4, 206 feet) and are clearly different forms, tentatively assigned to $G$. aff. G. caribbeanica (Bybell, pers. commun., 1990) and may represent older than 19a occurrences. Age determinations based on these two occurrences of a different Gephyrocapsa species are the only two that do not match interpretations based on the local biozonation or the major disconformities.

Detailed occurrences of the ostracodes (Cronin, unpublished data, 1990), foraminifers (Bybell and Poore, in press; Gibson and Margerum, in press), and nannofossils (Bybell and Poore, in press) in KAR-1 and OOR-17 can be graphically correlated based on local ranges of 252 specific identities (Fig. 6) following the method of Shaw (1964) and Edwards (1984). Ostracodes from OAR-2A/2 and XEN-3 have not been examined in detail, nor tabulated to allow detailed graphic correlation of those sections. Graphic correlation permits better understanding of depositional processes at specific intervals. For instance, the fourth interval (Fig. 6) shows significantly more sedimentation occurred at OOR-17 than KAR-1, which aids interpretation of the sediment accumulation curve developed later in the text. The paleontologic lines of correlation (L.O.C.) show an abrupt break from a lower line based on species occurrences in the basically uninterrupted upper Miocene/lowermost Pliocene sediments and the commonly interrupted Plio-Pleistocene. The break is better represented in OOR-17 than KAR-1.

Reliable radiometric dates were reported for three intervals within the Pleistocene for samples from EXPOE boreholes on Aranit Island (Szabo et al., 1985). We can correlate these horizons to the EXPOE borehole (XEN-3) on Enjebi Island utilized in Bybell and Poore (in press) and this study (Fig. 5). The $8 \mathrm{ka}$ 


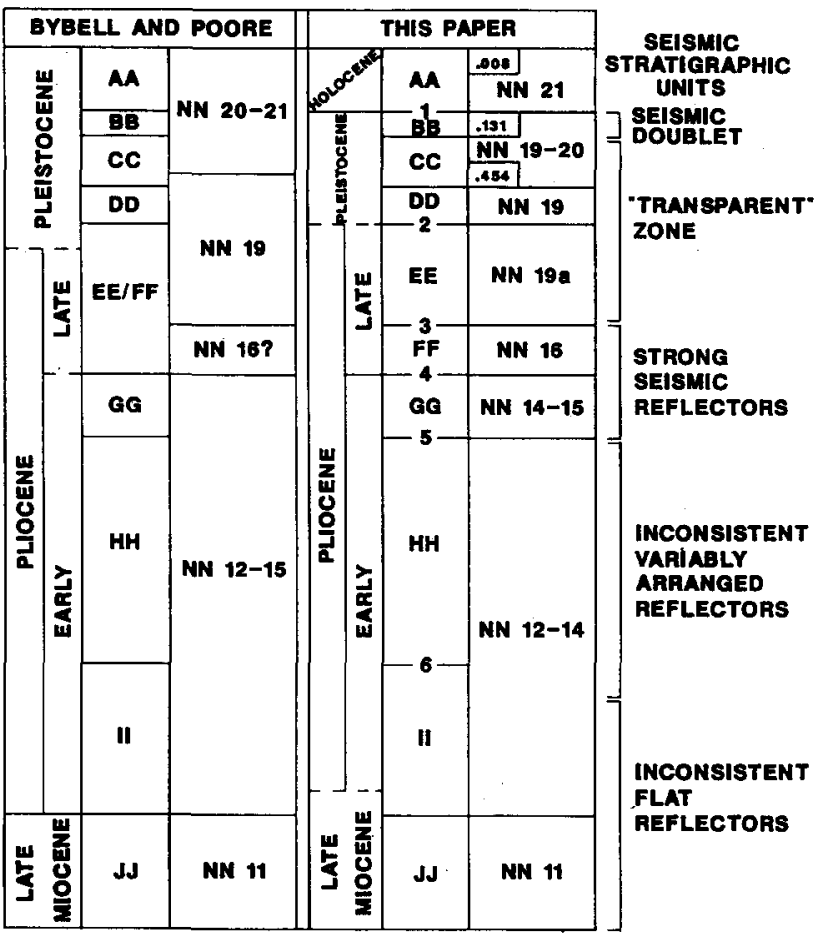

FIG. 5. Comparison of biostratigraphic dating of Bybell and Poore (in press) to that of this paper, which uses major disconformities as additional time lines to those of Bybell and Poore (in press). Local biozones of Cronin et al. (1986), nannofossil zones and seismic stratigraphic zones also shown.
$\mathrm{BP}$ age correlates to biozone AA. The $131 \pm 3 \mathrm{ka}$ BP age correlates to biozone BB. The $454 \pm 100 \mathrm{ka} \mathrm{BP}$ age correlates to the lower part of biozone $\mathrm{CC}$.

\section{Chemostratigraphy of Enewetak Reference Boreholes}

Wardlaw and Henry (1986) divided the stratigraphy of Enewetak into several sedimentary packages based largely on carbonate mineralogy. Such packages coincide with unaltered aragonite dominated Holocene sediments, mixed-mineralogy aragonite/calcite PlioPleistocene sediments, altered calcite-dominated Pliocene sediments, and unaltered aragonitedominated Miocene-Pliocene sediments (Fig. 7). There is a transitional zone from the altered to unaltered sediments in the Lower Pliocene.

Low $\delta^{13} \mathrm{C}$ and $\delta^{18} \mathrm{O}$ values relate to meteoric calcitization in paleosol and paleophreatic diagenetic environments (Quinn, 1991). Figures 7-10 show the weight percent calcite, $\delta^{18} \mathrm{O}$ and $\delta^{13} \mathrm{C}$ for the reference boreholes on Enewetak and their relation to major disconformities.

\section{General characteristics of the major disconformities}

The general characteristics of the shallow major disconformities in the reference boreholes at Enewetak Atoll are listed in Table 2. All major disconformities except disconformity 2 in KAR-1 and disconformity 5

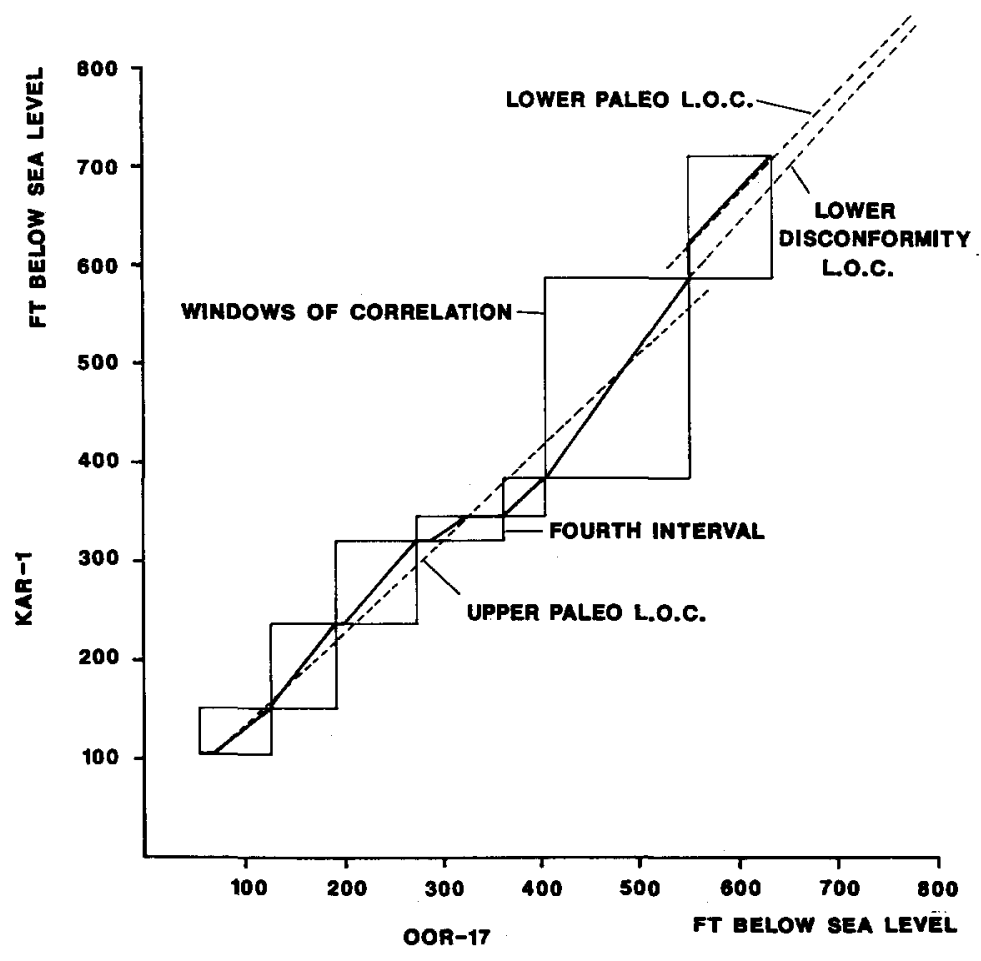

FIG. 6. Graphic correlation of boreholes KAR-1 and OOR-17. Correlation utilizes FADs and LADs of 252 species of ostracodes, larger forams, benthic forams, planktic forams and nannofossils (see text for references). L.O.C. (line of correlation) as solid line. Upper and lower paleo L.O.C. as dashed lines and based on entire section without using disconformities. Lower disconformity L.O.C. drawn by simply connecting to next lower disconformity as it would plot off the diagram. Windows of correlation defined by correlation space between disconformities. End of windows of correlation drawn at position of $\mathrm{II} / \mathrm{JJ}$ local biozone and NN $11 / \mathrm{NN} 12$ nannofossil zone boundary $(5.6 \mathrm{Ma})$. 


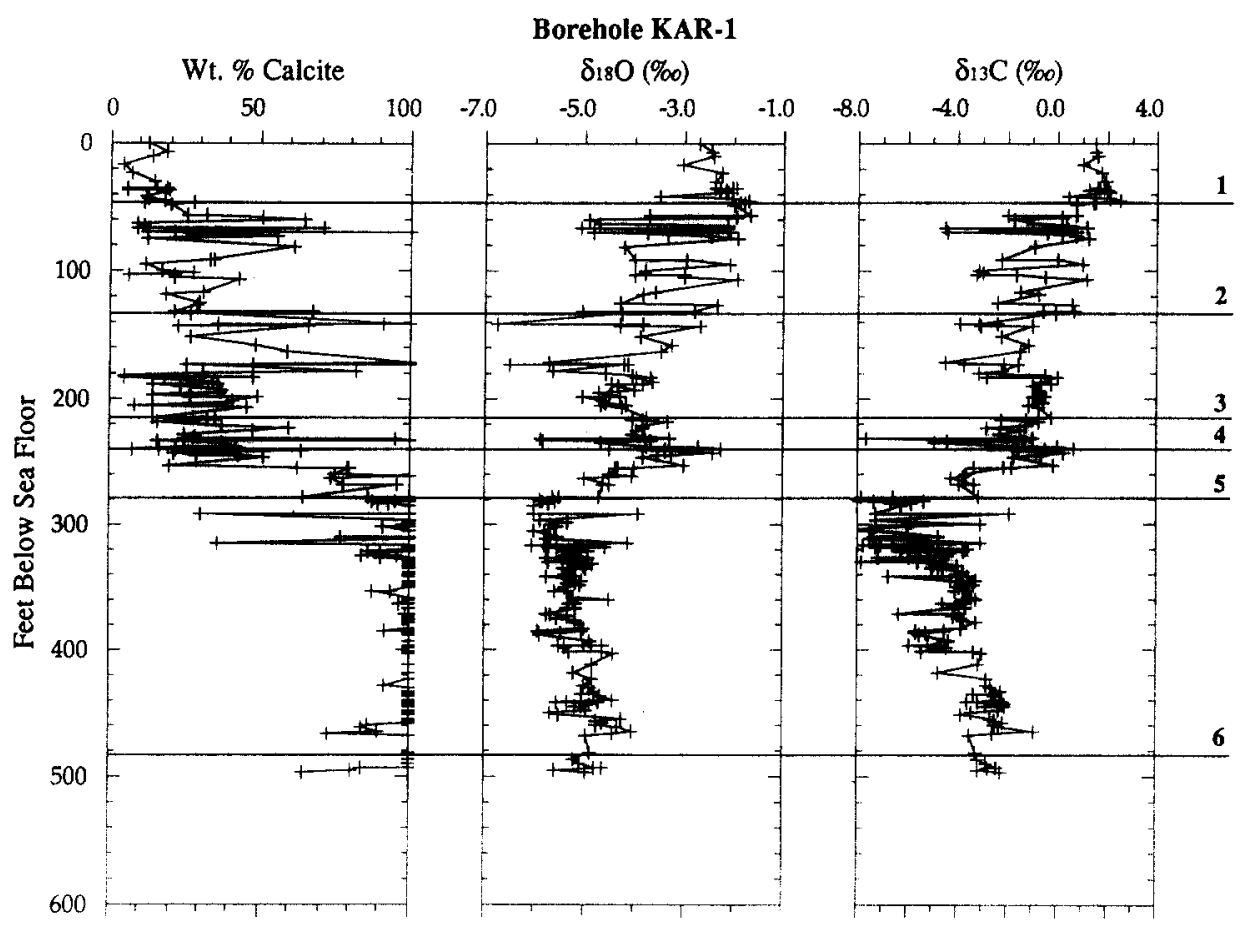

FIG. 7. Weight percent calcite, $\delta^{18} \mathrm{O}$ and $\delta^{13} \mathrm{C}$ for KAR-1, showing major disconformities.

in OOR-17 are associated with an increase in sonic velocity and density. Disconformity 1 is characterized by slight increases in cementation and porosity, and coincides with the loss of high-Mg calcite in the PlioPleistocene sediments below. Disconformities 2-4 are characterized by reasonably strong increases in cementation and common paleosol indicators (caliche, rhizoliths, soil, etc.). The seismic expression of discon- formity 2 is relatively weak and the lack of a geophysical signature in KAR-1 is consistent with observation. Disconformity 5 shows a generally strong mineralogic change except for OOR-17 where the pervasive change to calcite occurs at the overlying disconformity. Disconformity 5 also shows a strong increase in cementation and porosity, and a strong meteoric $\delta^{13} \mathrm{C}$ signature, except for OOR-17 which shows the strong meteoric

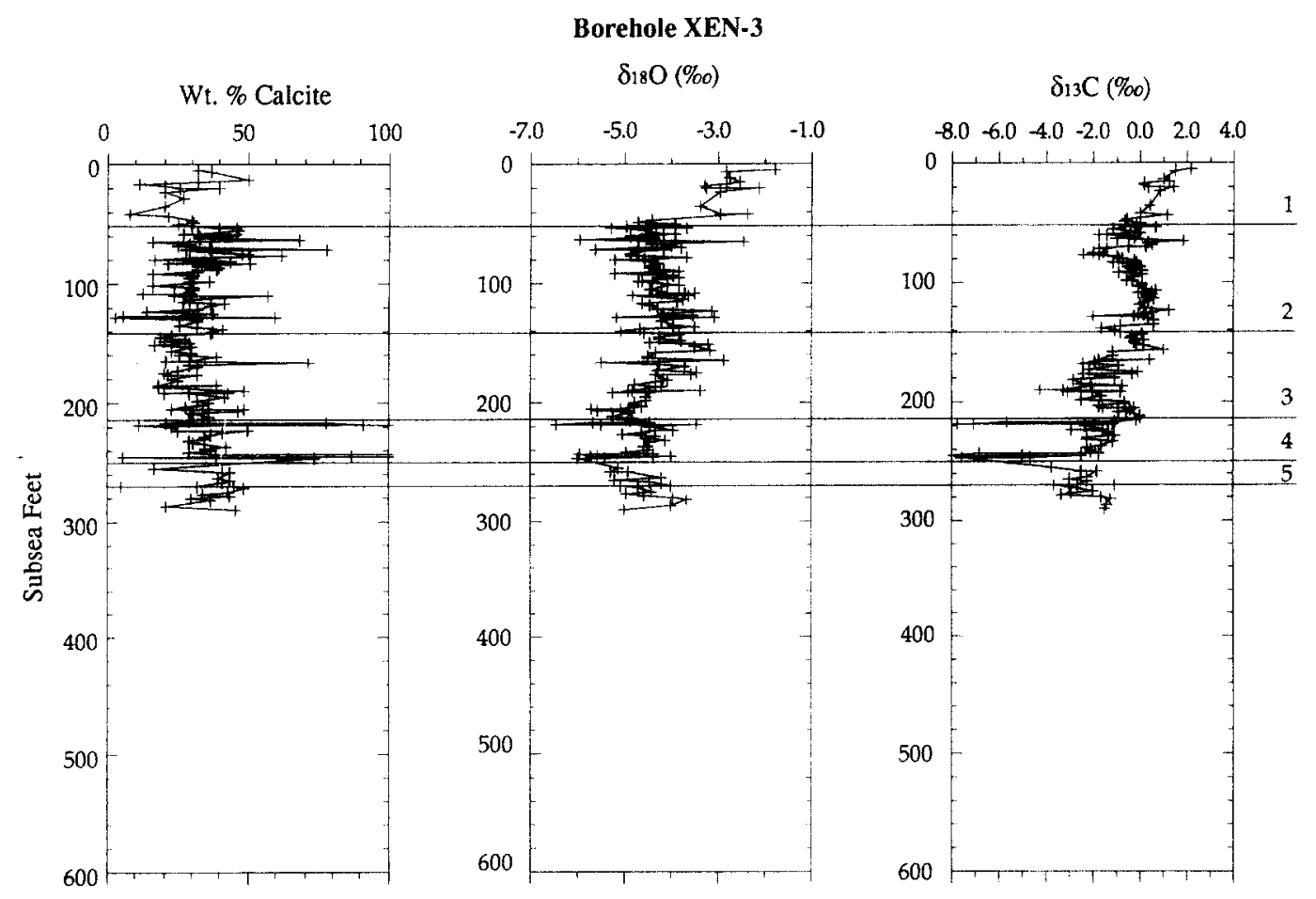

FIG. 8. Weight percent calcite, $\delta^{18} \mathrm{O}$ and $\delta^{13} \mathrm{C}$ for $\mathrm{XEN}-3$, showing major disconformities. 


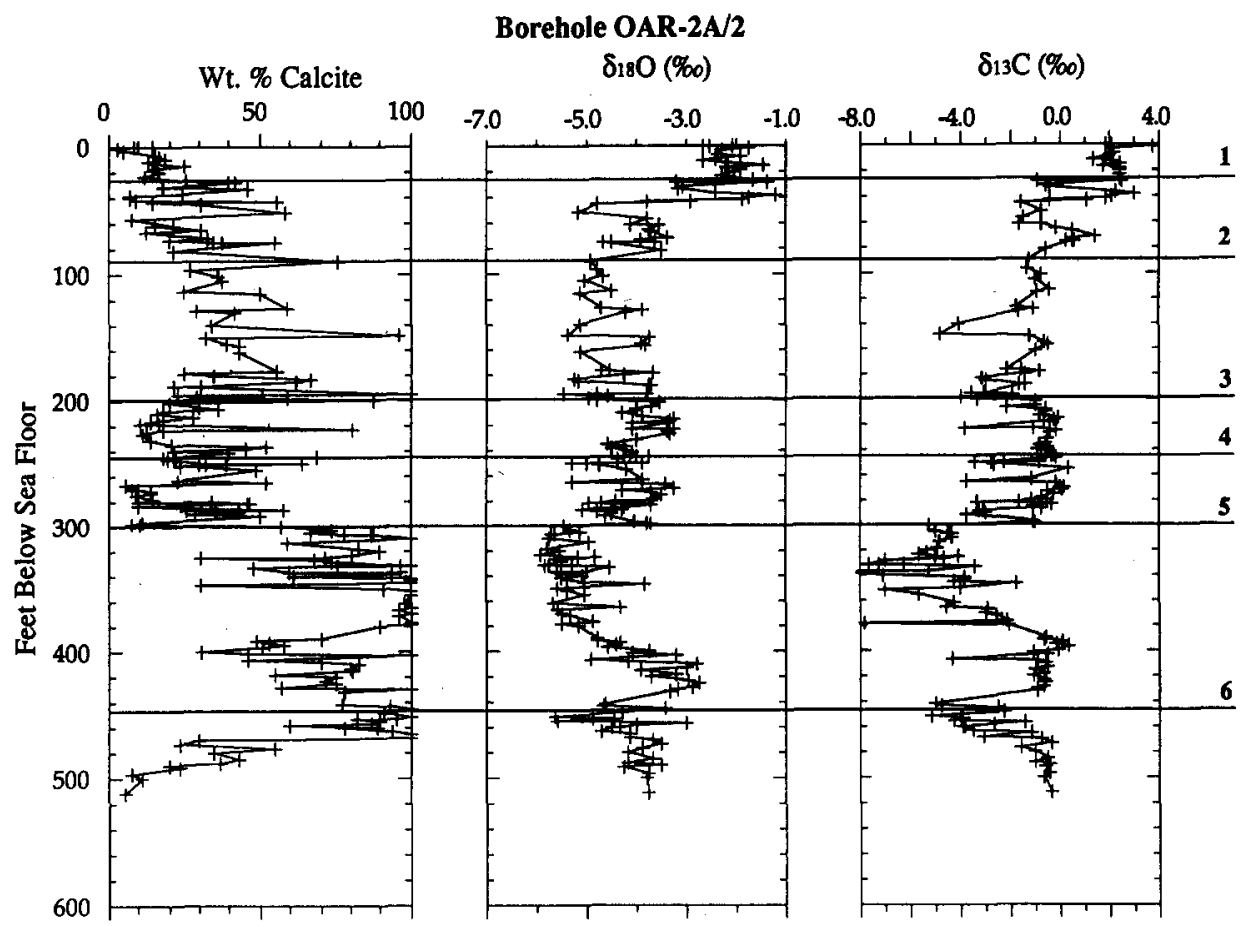

FIG. 9. Weight percent calcite, $\delta^{18} \mathrm{O}$ and $\delta^{13} \mathrm{C}$ for $\mathrm{OAR}-2 \mathrm{~A} / 2$, showing major disconformities.

$\delta^{13} \mathrm{C}$ signature at the overlying disconformity. The seismic expression of disconformity 5 in the OOR-17 borehole may be masked by the large increase in weight percent calcite in the overlying sediments, which would act to diminish the acoustical contrast in this interval. Disconformity 6 generally shows a strong density log increase but is otherwise obscured by the strong calcitization of Lower Pliocene sediments. Variations in the isotopic signatures are most likely produced by overprinting of diagenetic alteration and paleophreatic lenses from overlying disconformities. Disconformity 1 at OAR-2A/2 lacks a distinctive isotopic signature because the overlying 'Holocene' is all material redeposited by the OAK nuclear blast (Tremba et al., 1990), and disconformity 1 represents an exposed Pleistocene exposure surface with recent marine borings and cementation.

\section{Borehole OOR-17}

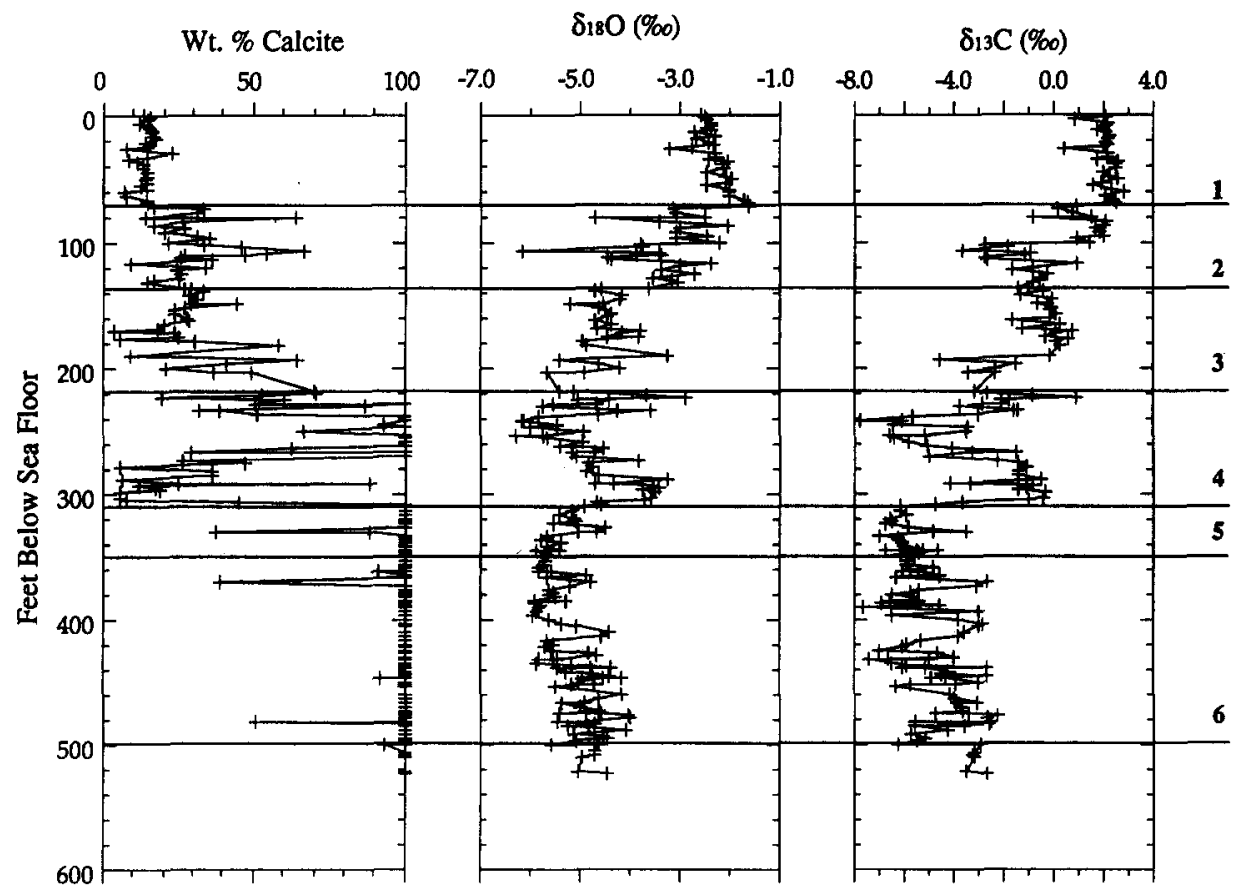

FIG. 10. Weight percent calcite, $\delta^{18} \mathrm{O}$ and $\delta^{13} \mathrm{C}$ for OOR-17, showing major disconformities. 
TABLE 2. Characteristics of major disconformities showing strong $(++)$, weak $(+)$, and no ( -$)$ indicators for each column

\begin{tabular}{|c|c|c|c|c|c|c|c|c|c|}
\hline Borehole & $\begin{array}{l}\text { Sonic } \\
\text { signature }\end{array}$ & $\begin{array}{l}\text { Density } \\
\log \end{array}$ & $\begin{array}{l}\text { Facies } \\
\text { change }\end{array}$ & $\begin{array}{l}\text { Mineralogic } \\
\text { change }\end{array}$ & $\begin{array}{l}\text { Increased } \\
\text { cementation }\end{array}$ & $\begin{array}{l}\text { Increased } \\
\text { porosity }\end{array}$ & $\begin{array}{l}\text { Paleosol } \\
\text { indicators }\end{array}$ & $\begin{array}{c}\delta^{18} \mathrm{O} \\
\text { signature }\end{array}$ & $\begin{array}{c}\delta^{13} \mathrm{C} \\
\text { signature }\end{array}$ \\
\hline \multicolumn{10}{|c|}{ Disconformity 1} \\
\hline KAR-1 & NA & NA & $+t$ & ++ & + & + & - & - & + \\
\hline XEN-3 & NA & NA & $+t$ & $t+$ & + & $t+$ & - & $+t$ & + \\
\hline OAR-2A/2 & NA & ++ & $+t$ & $+t$ & + & + & & - & - \\
\hline OOR-17 & ++ & ++ & ++ & ++ & ++ & + & + & ++ & + \\
\hline \multicolumn{10}{|c|}{ Disconformity 2} \\
\hline KAR-1 & - & - & ++ & ++ & + & - & + & $t+$ & + \\
\hline XEN-3 & NA & NA & - & + & ++ & - & ++ & ++ & ++ \\
\hline OAR-2A/2 & + & + & - & - & + & - & ++ & - & - \\
\hline OOR-17 & $t+$ & + & - & - & $+t$ & - & $+t$ & - & - \\
\hline \multicolumn{10}{|c|}{ Disconformity 3} \\
\hline KAR-1 & + & ++ & - & - & $+t$ & - & + & + & ++ \\
\hline XEN-3 & NA & NA & - & - & ++ & + & + & $+t$ & $+t$ \\
\hline OAR-2A/2 & + & + & + & - & $+t$ & + & + & - & + \\
\hline OOR-17 & + & + & - & + & ++ & ++ & + & - & - \\
\hline \multicolumn{10}{|c|}{ Disconformity 4} \\
\hline KAR-1 & + & + & + & - & $+t$ & $t+$ & ++ & + & + \\
\hline $\mathrm{XEN}-3$ & NA & NA & - & - & + & + & $+t$ & ++ & ++ \\
\hline OAR-2A/2 & $+t$ & + & + & - & $+t$ & $+t$ & $\because=$ & - & - \\
\hline OOR-17 & ++ & + & - & $+t$ & + & ++ & + & - & $+t$ \\
\hline \multicolumn{10}{|c|}{ Disconformity 5} \\
\hline KAR-1 & NA & ++ & + & ++ & ++ & ++ & - & ++ & ++ \\
\hline XEN-3 & $\mathrm{NA}$ & NA & + & + & ++ & + & + & $+t$ & $+t$ \\
\hline OAR-2A/2 & + & ++ & + & ++ & ++ & ++ & + & - & ++ \\
\hline OOR-17 & + & - & + & - & $+t$ & + & $\cdots$ & - & - \\
\hline \multicolumn{10}{|c|}{ Disconformity 6} \\
\hline KAR-1 & ++ & ++ & - & - & - & + & + & - & - \\
\hline XEN-3 & NA & NA & NA & NA & NA & NA & NA & NA & NA \\
\hline OAR-2A/2 & NA & ++ & + & ++ & + & $+t$ & - & - & ++ \\
\hline OOR 17 & $\mathrm{NA}$ & ++ & + & - & + & - & - & ++ & ++ \\
\hline
\end{tabular}

* Marine Hardground.

NA refers to Not Applicable, where either the logs were not taken or were poor due to extreme borehole rugosity, or the borehole not penetrating that horizon. The sonic signature and density log increase are from the downhole geophysical logs reported by Melzer (1986). Facies change and mineralogic change are from Henry et al. (1986), Tremba and Ristvet (1986) and Quinn (1989). Increased cementation, porosity, and paleosol data are from Henry et al. (1986) and Quinn (1989). Oxygen and carbon isotopic signatures are from Quinn (1989) and this paper.

\section{SEA-LEVEL HISTORY}

We refine our age model for Enewetak by 'tuning' the Enewetak age data for major disconformities (i.e. major sea-level lowstand events) to proxies based on sequence stratigraphy (Haq et al., 1987) and Oxygen Isotopic data from foraminifers (Prentice and Matthews, 1988) (Figs 11-13). The sequence stratigraphy proxy fits all the major hiatuses except disconformity 6 between $\mathrm{HH} / \mathrm{II}$ biozones and probable NN 12/NN 13 nannofossil zones. The Oxygen Isotope proxy indicates that periods of relatively rapid fluctuations in $\delta^{18} \mathrm{O}$ are expressed as hiatuses on Enewetak. All major hiatuses except disconformity 5 , between GG/HH biozones and probable NN 13/NN 14 nannofossil zones, are fitted. The Oxygen Isotope proxy also approximates all the minor disconformities (discontinuities recognized by Wardlaw and Henry, 1986) as single large sea-level lowstand events (shown as asterisks on Fig. 11).

\section{Sea-Level Highstands}

Temporal constraints on major disconformities are provided from nannofossil zone boundaries recognized in this study and/or from the global nannofossil chronostratigraphy (Berggren et al., 1985) and indicate the following ages are contained within the hiatuses represented by the major disconformities recognized at Enewetak; 0.1 Ma for disconformity 1 (NN 20/NN 21), $1.45 \mathrm{Ma}$ for disconformity $2(\mathrm{NN} \mathrm{19a/NN} \mathrm{19),} 2.1 \mathrm{Ma}$ for disconformity 4 (NN 17/NN 18), $3.55 \mathrm{Ma}$ for disconformity 4 (NN 15/NN 16), 4.1 Ma for disconformity 5 (NN 13/NN 14) and 4.5 Ma for disconformity 6 (NN 12/NN 13). The NN 11/NN 12 boundary (5.6 Ma) is also clearly discernible as the $\mathrm{J} / \mathrm{II}$ boundary in the cores. A sediment accumulation curve (Fig. 14), constructed from the age and stratigraphic position of these major disconformities, indicates that the present day topographic relation between reef tract (XEN-3) and the lagoon (KAR-1, OAR-2A/2, OOR-17) has persisted throughout the Neogene. Moreover, in all 


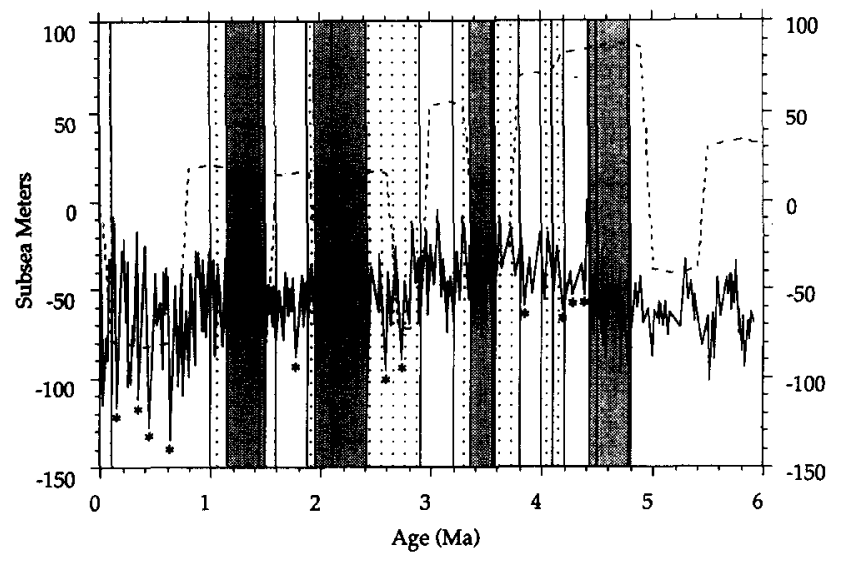

FIG. 11. Comparison of Enewetak age of hiatuses to sequence proxy and isotopic proxy.

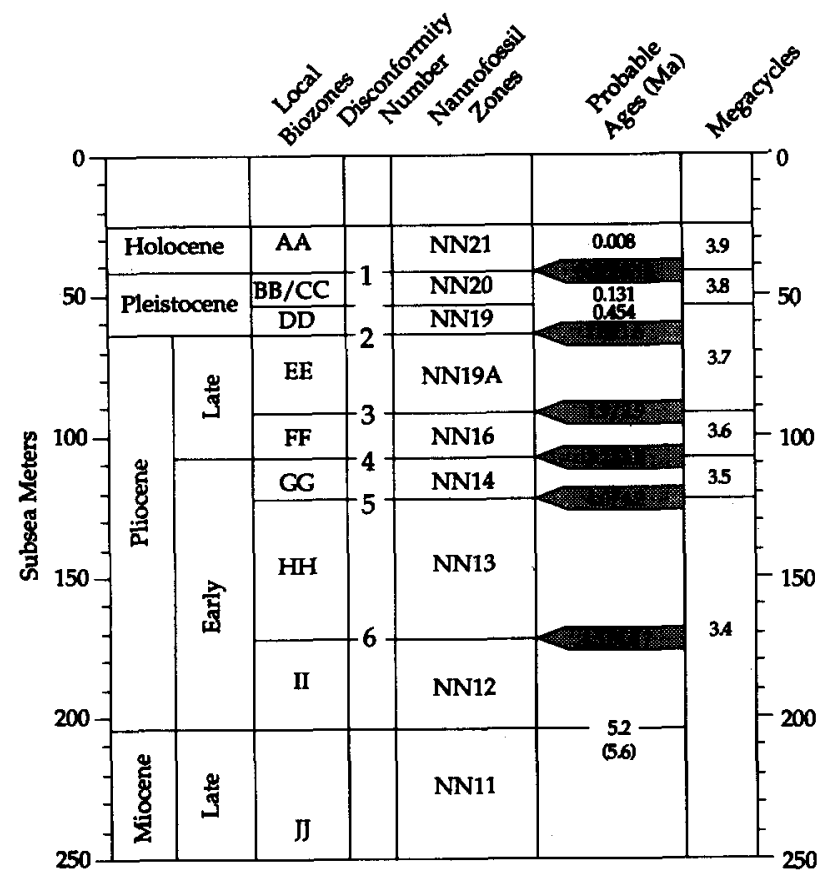

FIG. 12. Age of section by combining Enewetak constraints with sequence proxy.

intervals, except between disconformities 4 and 5 , the present day bathymetry of each of the lagoon borehole localities (KAR-1, $32 \mathrm{~m}$; OAR-2A/2, $34 \mathrm{~m}$; OOR-17, $17 \mathrm{~m}$ ) is maintained throughout the Neogene (Fig. 14). Foraminiferal grainstone, a sedimentary facies that dominates the interval between disconformities 4 and 5 , is presently found along the lagoon beach of Enewetak islands at water depths less than $7 \mathrm{~m}$.

Shallow-water carbonate sediment accumulates in the accommodation space created by sea-level change and subsidence and, because such sediments are deposited at or near sea level, the rate of accommodation can be approximated by sediment accumulation rate (e.g. Saller and Koepnick, 1990). Such a calculation using thicknesses and ages of sediments at Enewetak suggests an approximated mean accumulation and

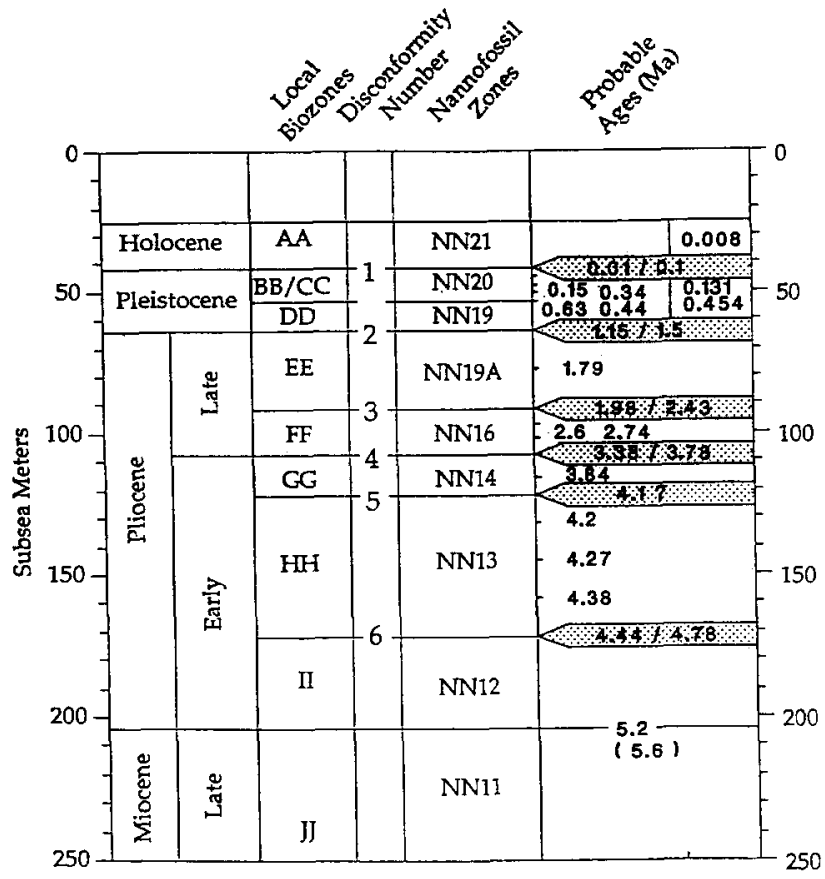

FIG. 13. Age of section by combining Enewetak constraints with isotopic proxy

accommodation rate of $32 \mathrm{~m} / \mathrm{Ma}$. Previous workers have suggested that the approximate accommodation curve at Enewetak may also be approximated subsidence curve for the atoll (Saller and Koepnick, 1990). We follow the suggestion of these workers and use a first-order approximation of atoll subsidence to be 32 $\mathrm{m} / \mathrm{Ma}$ during the Plio-Pleistocene. Such a value for subsidence rate is within the range of subsidence rates $(20-40 \mathrm{~m} / \mathrm{Ma}$ ) suggested by other workers (e.g. Halley and Ludwig, 1987, 1989a; Quinn and Matthews, 1990).

We take a conservative approach in our calculations of sea-level highstands and use low ( $25 \mathrm{~m} / \mathrm{Ma})$ and high $(40 \mathrm{~m} / \mathrm{Ma})$ subsidence rates to ensure that the sea-level model produced in this study captures the full range of possible sea-level solutions given the Enewetak data set. Furthermore, we take average present-day water depths at the three reference lagoon borehole localities $(25 \mathrm{~m})$ to approximate water depth above each disconformity, except at disconformities 4 and 5 where we approximate a water depth of $4 \mathrm{~m}$ in light of sedimentary facies considerations previously discussed (Figs 15 and 16).

\section{Sea-Level Lowstands}

The position of sea-level lowstands is much more difficult to constrain relative to the position of sea-level highstands, especially in the pervasively-calcitized Pliocene sequence at Enewetak. Previous workers have recognized the lowermost limit of meteoric diagenesis in the subsurface of Midway Island and used the position of the base of diagenetically-altered interval to constrain the maximum sea-level fall (Major and Matthews, 1983; Lincoln and Schlanger, 1987). The lowermost limit of meteoric diagenesis can be used to 


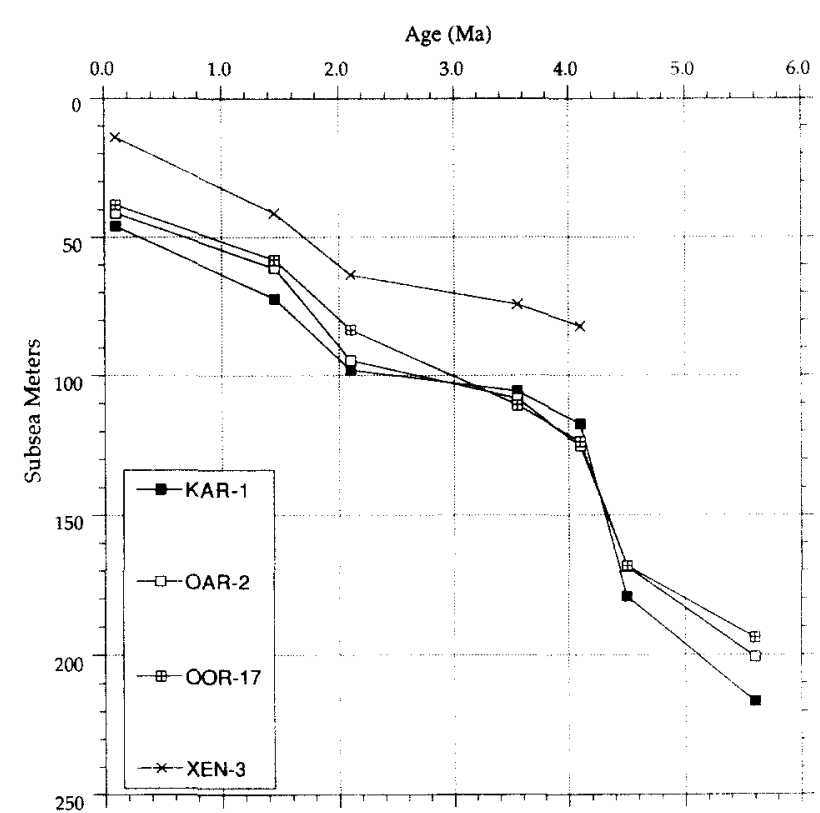

FIG. 14. Sediment accumulation curves for reference boreholes from Enewetak.

constrain the magnitude of sea-level fall because the position of the meteoric phreatic diagenetic environment closely approximates mean sea-level position, especially at mid-ocean islands (e.g. Major and Matthews, 1983; Quinn, 1991). Clearly, the reoccurrence of aragonite-rich sediments is sharply

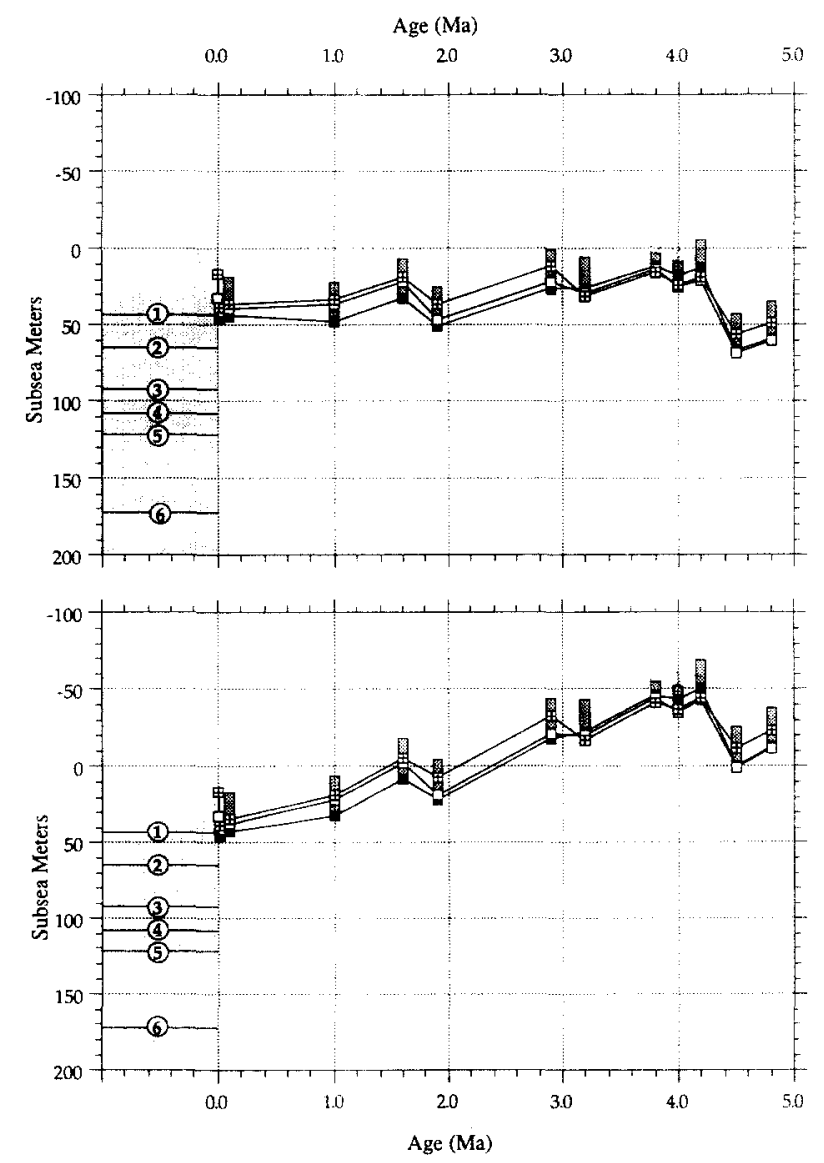

FIG. 15. Sea-level highstand calculations for subsidence rates of 25 $\mathrm{m} / \mathrm{Ma}$ and $40 \mathrm{~m} / \mathrm{Ma}$ with ages from Enewetak/sequence proxy model.

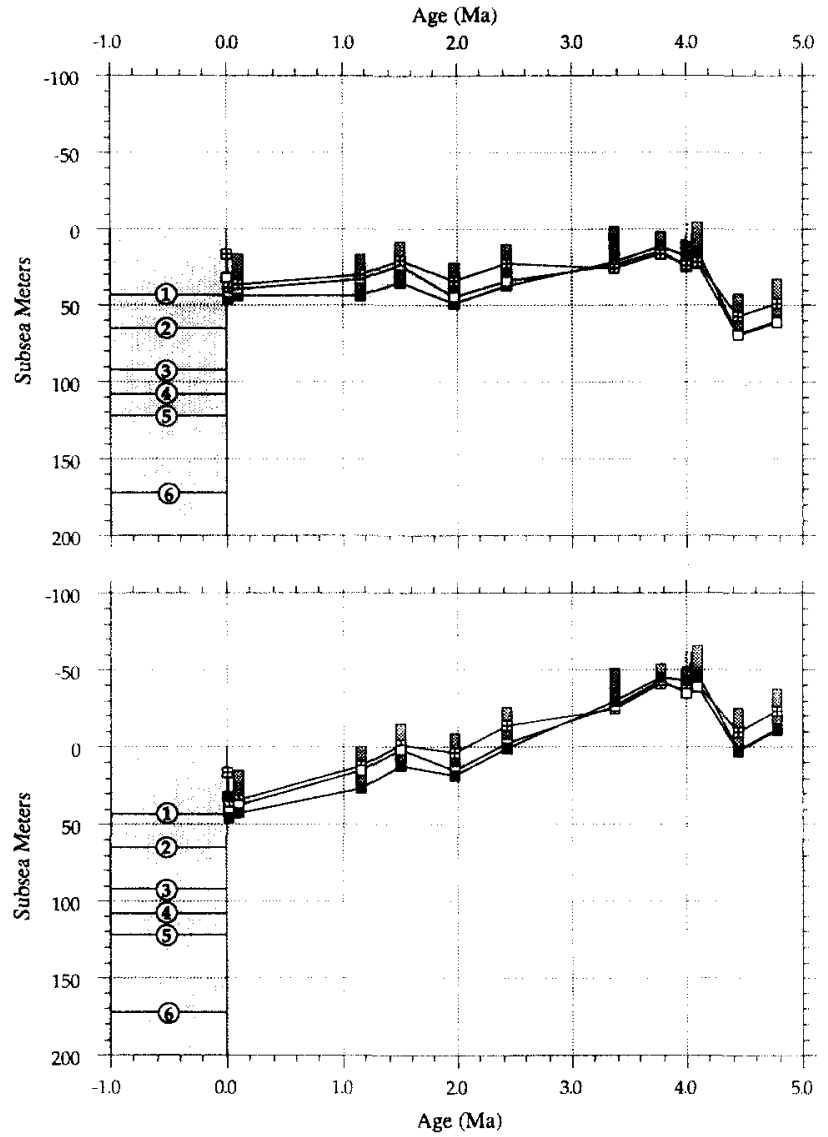

FIG. 16. Sea-level highstand calculations for subsidence rates of $25 \mathrm{~m} / \mathrm{Ma}$ and $40 \mathrm{~m} / \mathrm{Ma}$ with ages from Enewetak/isotope proxy model.

defined below disconformity 6 (refer to Figs 9 and 10). This depth also limits all succeeding zones of alteration. We will attempt to estimate the depths of the various zones of alteration for the major disconformities to define a more explicit sea-level model than using the lowermost zone as an absolute limit for each and every succeeding disconformity. The minor disconformities, because they do not extend across the lagoon, were probably associated with sea-level falls that were less than the depth of the lagoon (presently $44 \mathrm{~m}$ approximately, with a maximum depth of $62 \mathrm{~m}$ ). Similar to arguments developed to calculate highstands, the lagoon reference boreholes maintain the same relative position in relation to the island/reef tract borehole on the sediment accumulation curve, implying that the present relative topography was maintained resulting in similar sediment accommodations. That is, the topography we see today was likely to have been the topography throughout most of the Plio-Pleistocene and minor disconformities represent sea level falls of less than $44 \mathrm{~m}$. This also implies that no major dissolution or erosion took place along the atoll margin. We find no petrographic evidence for major subaerial erosion, in agreement with Quinn (1991).

The depth of alteration below disconformity 6 is an average of $12 \mathrm{~m}$ (range 11-13 $\mathrm{m}$ ) indicating a maximum sea-level fall of $12 \mathrm{~m}$. The depth of alteration below each succeeding disconformity can only be approxi- 
mated but cannot exceed this lowermost depth of alteration, following the arguments of Major and Matthews (1983). Disconformities 1 and 3 are the strongest seismic reflectors followed by, in order of decreasing strength, 4, 5, 6 and 2 . If we assume the degree of alteration is directly related to strength of a reflector, and the depth of alteration related to the degree of alteration (not unreasonable assumptions), we have a relative order of apparent depths of alteration. Further, we can look at lithologic sequences and estimate the depth of alteration associated with each major subaerial exposure surface. The depth of alteration below disconformity 5 is very difficult to calculate because it has been overprinted by paleophreatic lenses associated with sea-level falls forming disconformities 3 and 4 . The maximum depth of alteration associated with disconformities 3 and 4 appears to be no greater than the depth to disconformity 6 (approximately $80 \mathrm{~m}$ and $64 \mathrm{~m}$, respectively) because the disconformity still preserves its character and is preserved across the lagoon. It seems that the sea-level fall associated with disconformity 3 is in the same order as that associated with disconformity 4 (i.e. $64 \mathrm{~m}$ ). The sea-level fall associated with disconformity 5 then must be indicated by the severely altered zone below the disconformity that is approximately $12 \mathrm{~m}$ thick. Aragonite-rich sediments occur below disconformity 2 and above disconformity 3 , especially in KAR-1 and OOR-17. This suggests that the maximum depth of the alteration zone associated with disconformity 2 does not exceed the average depth to disconformity 3 , $25 \mathrm{~m}$. The Pleistocene, between disconformities 2 and 1 , represents short-term, large amplitude sea-level fluctuations that are too complicated for this preliminary speculative modeling.

\section{Sea-Level Curve}

Combining the lowstand values with the average highstand values (at a $32 \mathrm{~m} / \mathrm{Ma}$ subsidence rate) calculated from both the sequence proxy model and the isotope proxy model yields a low-resolution sea-level curve for the last $5 \mathrm{Ma}$ at Enewetak (Fig. 17). Though speculative, both the Enewetak/sequence proxy and Enewetak/isotope proxy yield very similar curves. The two curves show an early Pliocene lowstand of $17 \mathrm{~m}$ below present sea level with highstands at $29-36 \mathrm{~m}, 25$ $26 \mathrm{~m}, 20-25 \mathrm{~m}$ and $3-5 \mathrm{~m}$ above present sea level, and major lowstands at $33-37 \mathrm{~m}, 60-63 \mathrm{~m}$ and $32-33 \mathrm{~m}$ below present sea level. The last lowstand is in the Early Pleistocene.

\section{CONCLUSIONS}

Integration of seismic stratigraphy, lithostratigraphy and chemostratigraphy data from Enewetak Atoll suggest that subaerial exposure surfaces developed during major sea-level lowstands and have significant seismic, lithic, biotic and chemical signatures. Sea-level models based on the stratigraphic position and age of major disconformities suggest a maximum sea-level

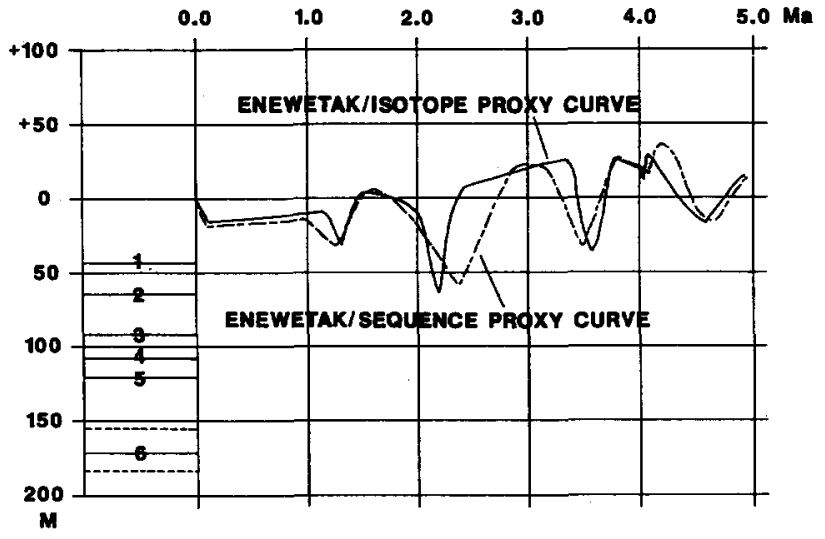

FIG. 17. Sea-level curves based on major disconformities of Enewetak, and a subsidence rate of $32 \mathrm{~m} / \mathrm{Ma}$ derived from Enewetak/ sequence proxy and Enewetak/isotope proxy models. The estimated depths of alteration associated with disconformities, when not the next underlying disconformity, are shown as dashed lines in generalized stratigraphic section shown at left of the diagram.

TABLE 3. Age and elevation of sea-level lowstands and highstands from sea-level model assuming a constant subsidence of $32 \mathrm{~m} / \mathrm{Ma}$ and using the age constraints shown in Fig. 12 (Enewetak/sequence proxy) and Fig. 13 (Enewetak/isotope proxy), and the derived highstand and lowstand constraints

\begin{tabular}{|c|c|c|c|}
\hline \multirow[b]{2}{*}{ Disconformity } & \multirow[b]{2}{*}{ Median age (Ma) } & \multicolumn{2}{|c|}{ Sea level* } \\
\hline & & Low & High $\dagger$ \\
\hline 1 & $0.09-0.1$ & - & - \\
\hline 2 & 1.3 & (-) $32-33$ & - \\
\hline 3 & $2.2-2.4$ & (-) $60-63$ & $(+) \quad 3-5$ \\
\hline 4 & $3.5-3.6$ & (-) $33-37$ & (+) $20-25$ \\
\hline 5 & $4.0-4.1$ & (+) $17-12$ & (+) $25-26$ \\
\hline 6 & 4.6 & (-) 17 & (+) $29-36$ \\
\hline
\end{tabular}

Values plotted on Fig. 17: *in meters above $(+)$ or below $(-)$ present sea level; tindicated by overlying sediments below next disconformity.

highstand elevation of $36 \mathrm{~m}$ above present sea level, and a maximum sea-level lowstand elevation of $63 \mathrm{~m}$ below present sea level for the Pliocene. The age of each disconformity and the calculated lowstand associated with it, and the highstand developed between disconformities, are summarized in Table 3.

\section{REFERENCES}

Berggren, W.A., Kent, D.V., Flynn, J.J. and Van Couvering, J.A. (1985). Cenozoic geochronology. Geological Society of America Bulletin, 96, 1407-1418.

Bybell, L.M. and Poore, R.Z. Calcareous nannofossils and planktic foraminifers from Enewetak Atoll, Marshall Islands, western Pacific Ocean. U.S. Geological Survey Professional Paper 1513-C (in press).

Couch, R.F. Jr, Fetzer, J.A., Goter, E.R., Ristvet, B.L., Tremba, E.L., Walter, D.R. and Wendland, V.P. (1975). Drilling operations of Eniwetok Atoll during Project EXPOE. Air Force Weapons Laboratory Technical Report AFWL-TR-75-216, $270 \mathrm{pp}$. Cronin, T.M., Brouwers, E.M., Bybell, L.M., Edwards, L.E., Gibson, T.G., Margerum, R. and Poore, R.Z. (1986). Pacific Enewetak Atoll Crater Exploration (PEACE) Program, Enewetak Atoll, Republic of the Marshall Islands; Part 2: Paleontology and biostratigraphy application to OAK and KOA craters. U.S. Geological Survey Open-File Report 87-665, 39 pp. 
Edwards, L.E. (1984). Insights on why graphic correlation (Shaw's method) works. Journal of Geology, 92, 583-597.

Gibson, T.G. and Margerum, R. Larger foraminifer biostratigraphy of PEACE boreholes, Enewetak Atoll, Marshall Islands. U.S. Geological Survey Professional Paper 1513-D (in press).

Grow, J.A., Lee, M.W., Miller, J.J., Agena, W.F., Hampson, J.C., Foster, D.S. and Woellner, R.A. (1986). Multichannel seismicreflection survey of KOA and OAK craters. In: Folger, D.W. (ed.), Sea-floor observations and subbottom seismic characteristics of OAK and KOA craters, Enewetak Atoll, Marshall Islands. U.S. Geological Survey Bulletin 1678-D, $46 \mathrm{pp}$

Halley, R.B. and Ludwig, K.R. (1987). Disconformities and Srisotope stratigraphy reveal a Neogene sea-level history from Enewetak Atoll, Marshall Islands, Central Pacific. Geological Society of America Abstracts with Programs, 19, 1370

Halley, R.B. and Ludwig, K;R. (1989a). Ancient sea levels from atoll stratigraphy: the Enewetak model. American Geophysical Union Abstracts with Programs, 70, 691

Halley, R.B. and Ludwig, K.R. (1989b). Reply on "Strontiumisotope stratigraphy of Enewetak Atoll". Geology, 7, 192-193.

Haq, B.U., Hardenbol, J. and Vail, P.R. (1987). Chronology of fluctuating sea levels since the Triassic. Science, 235, 1156-1167.

Henry, T.W. and Wardlaw, B.R. (1991). Introduction to geological and geophysical investigations of Enewetak Atoll, Republic of the Marshall Islands. U.S. Geological Survey Professional Paper 1513-A, $29 \mathrm{pp}$.

Henry, T.W., Wardlaw, B.R., Skipp, B., Major, R.P. and Tracey, J.I. Jr (1986). Pacific Enewetak Atoll Crater Exploration (PEACE) Program, Enewetak Atoll, Republic of the Marshall Islands; Part 1: Drilling operations and descriptions of boreholes in vicinity of KOA and OAK craters. U.S. Geological Survey OpenFile Report 86-419, 583 pp.

Lincoln, J.M. and Schlanger, S.O. (1987). Miocene sea-level falls related to the geologic history of Midway Atoll. Geology, 15, 454-457.

Ludwig, K.R., Halley, R.B., Simmons, K.R. and Peterman, Z.E. (1988). Sr isotope stratigraphy of Enewetak Atoll. Geology, 16, 173-177.

Major, R.P. and Matthews, R.K. (1983). Isotopic composition of bank margin carbonates on Midway Atoll: Amplitude constraint on post-early Miocene eustasy. Geology, 11, 335-338.

Melzer, L.S. (1986). Downhole geophysical logs. In: Henry, T.W. and Wardlaw, B.R. (eds), Pacific Enewetak Atoll Crater Exploration (PEACE) Program, Enewetak Atoll, Republic of the Marshall Islands; Part 3: Stratigraphic analysis and other geologic and geophysical studies in vicinity of KOA and OAK craters. U.S. Geological Survey Open-File Report 86-555, 7, $32 \mathrm{pp}$.

Prentice, M.L. and Matthews, R.K. (1988). Cenozoic ice volume history: Development of a composite oxygen isotope record. Geology, 16, 963-966.
Quinn, T.M. (1989). The Post-Miocene Meteoric Diagenetic and Glacioeustatic History of Enewetak Atoll: Borehole Study and Forward Modeling Results, unpublished Ph.D. Dissertation, Brown University, Providence, Rhode Island, 484 pp.

Quinn, T.M. Meteoric diagenesis of Plio-Pleistocene limestones at Enewetak. Journal of Sedimentary Petrology, 61 (5) (in press).

Quinn, T.M., Lohmann, K.C. and Halliday, A.N. Strontium-isotope stratigraphy as a correlative tool in shallow-water carbonate sequences: Implications of new data from Enewetak Atoll (in press).

Quinn, T.M. and Matthews, R.K. (1990). Post-Miocene diagenetic and eustatic history of Enewetak Atoll: Model and data comparison. Geology, 18, 942-945.

Robb, J.M., Foster, D.S., Folger, D.W., Hampson, J.C and Woellner, R.A. (1986). Single-channel seismic survey of OAK and KOA craters. In: Folger, D.W. (ed.), Sea-floor observations and subbottom seismic characteristics of OAK and KOA craters, Enewetak Atoll, Marshall Islands. U.S. Geological Survey Bulletin 1678-C, $51 \mathrm{pp}$

Saller, A.H. and Koepnick, R.B. (1990). Eocene to early Miocene growth of Enewetak Atoll: Insight from strontium-isotope data Geological Society of America Bulletin, 102, 381-390.

Shaw, A.B. (1964). Time in Stratigraphy. McGraw-Hill, New York $365 \mathrm{pp}$.

Szabo, B.J., Tracey, J.I. Jr and Goter, E.R. (1985). Ages of subsurface stratigraphic intervals in the Quaternary of Enewetak Atoll, Marshall Islands. Ouaternary Research, 23, 54-61.

Tremba, E.L. and Ristvet, B.L. (1986). X-ray diffraction mineralogy. In: Henry, T.W. and Wardlaw, B.R. (eds), Pacific Enewetak Atoll Crater Exploration (PEACE) Program; Part 3: Stratigraphic analysis and other geologic and geophysical studies in vicinity of KOA and OAK craters. U.S. Geological Survey Open-File Report $86-555,4,49 \mathrm{pp}$

Tremba, E.L., Ristvet, B.L., Wardlaw, B.R., Henry, T.W., Schatz, J.F. and Couch, R.F. (1990). A summary of the interim findings of the Pacific Enewetak Atoll Crater Exploration (PEACE) Program. Defense Nuclear Agency Technical Report DNA-TR-88-289, $262 \mathrm{pp}$

Wardlaw, B.R. and Henry, T.W. (1986). Physical stratigraphic framework. In: Henry, T.W. and Wardlaw, B.R. (eds), Pacific Enewetak Atoll Crater Exploration (PEACE) Program, Enewetak Atoll, Republic of the Marshall Islands; Part 3: Stratigraphic analysis and other geologic and geophysical studies in vicinity of KOA and OAK craters. U.S. Geological Survey Open-File Report $86-555,2,36 \mathrm{pp}$

Wardlaw, B.R. (1989). Comment on "Strontium-isotope stratigraphy of Enewetak Atoll". Geology, 17, 190-191. 